\title{
A quantitative case study assessment of changes to hepatic metabolism from nonlactating grazing dairy cows consuming a large proportion of their diet as fodder beet
}

\author{
T. M. Grala, ${ }^{1}$ R. R. Handley, ${ }^{2,3}$ C. V. C. Phyn, ${ }^{1}$ J. R. Roche,,${ }^{1,3 *}$ and D. E. Dalley ${ }^{4} \dagger$ \\ ${ }^{1}$ DairyNZ Ltd., Newstead, Hamilton 3201, New Zealand \\ ${ }^{2}$ DairyNZ Ltd., Auckland 1010, New Zealand \\ ${ }^{3}$ School of Biological Sciences, University of Auckland, Auckland 1010, New Zealand \\ ${ }^{4}$ DairyNZ Ltd., Canterbury Agriculture and Science Centre, Lincoln, Canterbury 7608, New Zealand
}

\section{ABSTRACT}

Because of its high yield and the ability of cows to graze it in situ, fodder beet (FB) has become a popular crop in grazing systems, particularly for nonlactating cows. Due to its high sugar content, however, the transition to FB must be managed carefully to avoid rumen acidosis and associated metabolic dysfunction. The initial consumption of $\mathrm{FB}$ reduces ruminal $\mathrm{pH}$; however, it is unclear whether this affects liver metabolism and results in systemic inflammation, as has been reported during subacute ruminal acidosis from high-grain diets. We used a quantitative case study approach to undertake additional measurements on a project demonstrating the effects of FB on urinary nitrogen excretion. The objective of our component, therefore, was to determine whether the inclusion of high rates of FB in the diet of nonlactating cows changed indicators of hepatic metabolism relative to a standard diet for nonlactating grazing cows. During the nonlactating period, multiparous, pregnant Holstein-Friesian cows were randomly assigned ( $\mathrm{n}=15$ per treatment) to either pasture (8 $\mathrm{kg}$ of DM/cow per day) with corn silage (4 $\mathrm{kg}$ of DM/ cow per day; PA) or transitioning onto an FB diet (8 $\mathrm{kg}$ of $\mathrm{DM} / \mathrm{cow}$ per day) with pasture silage (4 $\mathrm{kg}$ of $\mathrm{DM} /$ cow per day; BT) over $14 \mathrm{~d}$. Blood was sampled and the liver was biopsied during the adaptation period and after $7 \mathrm{~d}$ of full diet allocation. The hepatic expression of genes involved in peroxisomal oxidation was increased in cows adapting to FB, whereas the expression of genes involved in mitochondrial oxidation was increased when cows were on their full allocation of FB. These results indicate changes to fatty acid metabolism

Received November 18, 2018.

Accepted May 7, 2019.

${ }^{*}$ Current address: Ministry for Primary Industries, Pastoral House, Lambton Quay, Wellington 6011, New Zealand.

†Corresponding author: dawn.dalley@dairynz.co.nz with FB consumption. Expression of 2 genes involved in the unfolded protein response was greater during the adaptation period in cows consuming $\mathrm{FB}$, potentially reflecting negative effects of transitioning onto the FB diet on hepatic metabolism. Interestingly, expression of genes involved in the methionine cycle was increased in the BT cows. We hypothesize that this is a result of FB betaine absorption, although it is unclear to what extent betaine escapes ruminal degradation. While on the full diet allocation, there were lower serum concentrations of markers of hepatic stress in BT cows and no difference in expression of genes involved in oxidative stress compared with pasture-fed cows. However, there was an increase in plasma haptoglobin concentrations, indicative of an acute inflammatory response in BT cows. From this case study, we conclude that the results indicate no negative effects of the FB diet on liver metabolism and, possibly, positive effects on hepatic function. It appears, therefore, that the transition of nonlactating cows onto an FB diet can be managed to minimize the negative effects of the high sugar intake. Further research on the amount of betaine that escapes ruminal degradation in cows consuming $\mathrm{FB}$ would be of value to better understand whether betaine reduces liver damage in dairy cows consuming FB.

Key words: grazing, acidosis, unfolded protein response, methionine cycle

\section{INTRODUCTION}

In many seasonal pasture-based systems, cows are nonlactating during the winter and are often managed on fodder crops (Atkins et al., 2014; Edwards et al., 2014) because lower feed, labor, bedding, and machinery costs are involved compared with housing and mechanized feeding options. One of the crops becoming increasingly popular due to very high DM yields (Atkins et al., 2015) is fodder beet (FB), a subspecies of Beta vulgaris L. 
Both the bulb and the leaf of the FB plant can be consumed, either as harvested plants or grazed in situ. The bulb is typically 50 to $80 \%$ sugar but low in CP and NDF (Dalley et al., 2017). Due to its high palatability and the rapid fermentation of sugar, the transition onto FB must be managed carefully to avoid ruminal acidosis, particularly when being grazed in situ and where individual cow DMI cannot be controlled (Gibbs, 2011). To minimize negative effects on ruminal $\mathrm{pH}$, farmers are currently advised to transition dairy cows onto FB slowly, increasing the allocation by $1 \mathrm{~kg}$ of DM every $2 \mathrm{~d}$ over at least 2 wk until ad libitum intake is achieved (Gibbs, 2011; Atkins et al., 2014).

Despite these management guidelines at a herd level, variations in individual cow consumption can result in subclinical and clinical ruminal acidosis. Acidosis has been reported to promote LPS release from gram-negative bacteria in the rumen (Plaizier et al., 2008), which can cause a systemic inflammatory response; however, this mechanism is dependent on the diet that induced acidosis (Plaizier et al., 2012). Studies in goats have described changes in the inflammatory response (Chang et al., 2015) and in hepatic protein expression (Jiang et al., 2014) in response to low ruminal $\mathrm{pH}$. In cows, ruminal acidosis decreased hepatic expression of genes involved in fatty acid (FA) transport and oxidation (Xu et al., 2015), indicating changes to lipid metabolism in cows with low ruminal pH. Additionally, Abaker et al. (2017) reported altered activity and expression of genes involved in oxidative stress in the liver of cows with ruminal acidosis caused by a high-grain diet, indicating liver stress.

Although the initial exposure to an FB diet leads to changes in ruminal $\mathrm{pH}$, it is unclear whether this feed alters liver metabolism and systemic inflammation. There is also uncertainty about whether any changes, if present, occur only during the transition onto the crop or throughout the feeding period. Therefore, we hypothesized that the change from a typical diet for grazing nonlactating dairy cows to a mainly FB-based diet involves complex nutritional and metabolic adaptations, with potential consequences for hepatic health and metabolism. We used a case study approach to evaluate the effect of the inclusion of high rates of FB in the diet of nonlactating dairy cows on liver metabolism and inflammatory state by undertaking blood and liver tissue sampling from cows in a trial designed to measure the effects of dietary FB on urine nitrogen excretion.

\section{MATERIALS AND METHODS}

This study was conducted at the DairyNZ Scott Farm, Hamilton, New Zealand $\left(37^{\circ} 46^{\prime} \mathrm{S}, 175^{\circ} 18^{\prime} \mathrm{E}\right)$ during May and June 2016. All procedures had prior approval (RAEC 13866) of the Ruakura Animal Ethics Committee, Hamilton, New Zealand.

\section{Experimental Design and Treatments}

A grazing experiment designed to measure individual cow urine excretion (Shepherd et al., 2017) from 2 contrasting nonlactating cow diets provided a platform for a quantitative case study approach to investigate the effects of FB feeding on markers of stress and hepatic metabolism. During the seasonal, nonlactating period (May 2016), 30 multiparous, pregnant $(211 \pm 19 \mathrm{~d}$ of gestation; mean $\pm \mathrm{SD}$ ) Holstein-Friesian cows were randomly assigned ( $\mathrm{n}=15$ per treatment) to either a diet of fresh pasture ( $8 \mathrm{~kg}$ of DM/cow) with corn silage (4 kg of DM/cow; PA) or gradually transitioning onto an FB diet $(8 \mathrm{~kg}$ of DM/cow) with pasture silage $(4 \mathrm{~kg}$ of DM/cow; BT). Cows assigned to the BT group were transitioned onto the FB over a 15-d period (adaptation period) and then offered the full allocation of $\mathrm{FB}$ for 10 d (treatment period). Two BT cows were removed from the experiment due to suspected clinical ruminal acidosis, 1 during the adaptation period and 1 during the treatment period. Both animals made a full recovery. Three PA cows were removed due to high $(<800 \mathrm{IU} / \mathrm{L})$ plasma $\gamma$-glutamyl transferase (GGT) concentrations at d 7, probably due to a pre-experimental natural facial eczema challenge associated with grazing pasture. Data from these cows were not used for subsequent analysis.

\section{Grazing Management and Supplementary Feeding}

Before the start of the experiment, cows were grazed in the same paddock and were offered perennial ryegrass-white clover pasture $(\sim 12 \mathrm{~kg}$ of $\mathrm{DM} /$ cow per day).

Pasture-Based Diet. From d 0, PA cows were offered $4 \mathrm{~kg}$ of DM corn silage/cow per day in the morning in addition to a daily pasture allocation of $8 \mathrm{~kg}$ of $\mathrm{DM} /$ cow per day. Group DMI of pasture was estimated from pre- and postgrazing pasture mass every $3 \mathrm{~d}$ using a rising plate meter with an electronic counter (Farmworks, Palmerston North, New Zealand) calibrated as described by Roche et al. (2005). Pregrazing pasture mass was $3,554( \pm 516.3) \mathrm{kg}$ of $\mathrm{DM} / \mathrm{ha}$. The PA cows were maintained on this diet for the duration of the experiment.

FB Diet. Fodder beets (Beta vulgaris cv. Robbos; New Zealand Agriseeds, Christchurch, NZ) were sown in early November, and feeding commenced in April. From d 0, BT cows were adapted to the FB diet over a 15-d period (Figure 1). The FB allocation started at 1 
$\mathrm{kg}$ of $\mathrm{DM} /$ cow per day and increased by $0.5 \mathrm{~kg}$ of DM/ cow per day until the final allocation $(8 \mathrm{~kg}$ of $\mathrm{DM} / \mathrm{cow}$ per day) was achieved. Until cows consumed $5.5 \mathrm{~kg}$ of DM FB/cow per day, FB (whole plant) was hand harvested daily and offered to the cows in a pasture paddock following their daily allocation of pasture silage (4 $\mathrm{kg}$ of DM/cow per day). Once cows were consuming at least $5.5 \mathrm{~kg}$ of $\mathrm{DM} \mathrm{FB} / \mathrm{d}$ on d 10, they were shifted to graze the FB crop. Pasture silage was offered to the BT cows $2 \mathrm{~h}$ prior $(\sim 0800 \mathrm{~h})$ to the daily FB allocation $(\sim 1000 \mathrm{~h})$ at $4 \mathrm{~kg}$ of $\mathrm{DM} / \mathrm{cow}$ per day for $8 \mathrm{~d}$.

The pasture allocation decreased from 6 to $2.5 \mathrm{~kg}$ of $\mathrm{DM} /$ cow during the first $9 \mathrm{~d}$ before the cows were shifted to graze the FB crop. To minimize the risk of acidosis once cows were grazing FB from d 10, pasture silage was initially offered at $6.5 \mathrm{~kg}$ of $\mathrm{DM} / \mathrm{cow}$, and this was reduced to $4 \mathrm{~kg}$ of $\mathrm{DM} /$ cow over the rest of the adaptation period. Pasture silage was made from perennial ryegrass-white clover pasture, which was grown, mown, conditioned, wilted, and baled the previous spring from paddocks at the same site as the study. By d 15, BT cows were on the full allocation of $8 \mathrm{~kg}$ of DM FB/cow and $4 \mathrm{~kg}$ of DM pasture silage/cow. They were offered this diet for a further $10 \mathrm{~d}$. Fodder beet refusals were estimated daily by collecting and weighing all residual FB from $3 \times 1 \mathrm{~m}^{2}$ quadrats in the days' allocation and determining the DM percentage.

\section{Feed Sampling and Measurements}

Representative pasture (3 daily) samples were collected on 3 consecutive days during the treatment period (d 16-18). Pasture was hand-clipped to the predicted grazing height immediately before grazing. Corn silage samples were collected weekly $(\mathrm{n}=3)$, and pasture silage samples were collected from a core sample from each bale $(\mathrm{n}=4)$. The pasture and silage samples were bulked within feed type before analysis. Fodder beet yield was estimated on $3 \mathrm{~d} / \mathrm{wk}$ by harvesting $2-\mathrm{m} \times$ 2 -m adjacent row lengths $\left(4 \mathrm{~m}^{2}\right.$ in total $)$ in each day's allocation. Subsamples of bulb and leaf were collected from these areas and bulked before analysis.

Duplicate subsamples of all feeds were oven dried either at $95^{\circ} \mathrm{C}$ for $72 \mathrm{~h}$ to determine DM content or at $65^{\circ} \mathrm{C}$ for $72 \mathrm{~h}$ for subsequent analysis of nutrient composition. Samples were then ground to pass through a 0.5-mm sieve (Christy Laboratory Mill, Suffolk, UK) and analyzed for chemical composition by near-infrared reflective spectroscopy (Hill Laboratories, Hamilton, New Zealand). Composition of pasture, corn silage, FB, and pasture silage is presented in Table 1. Group water intakes were measured at $0800 \mathrm{~h}$ daily for the 10-d treatment period from troughs within the pad-

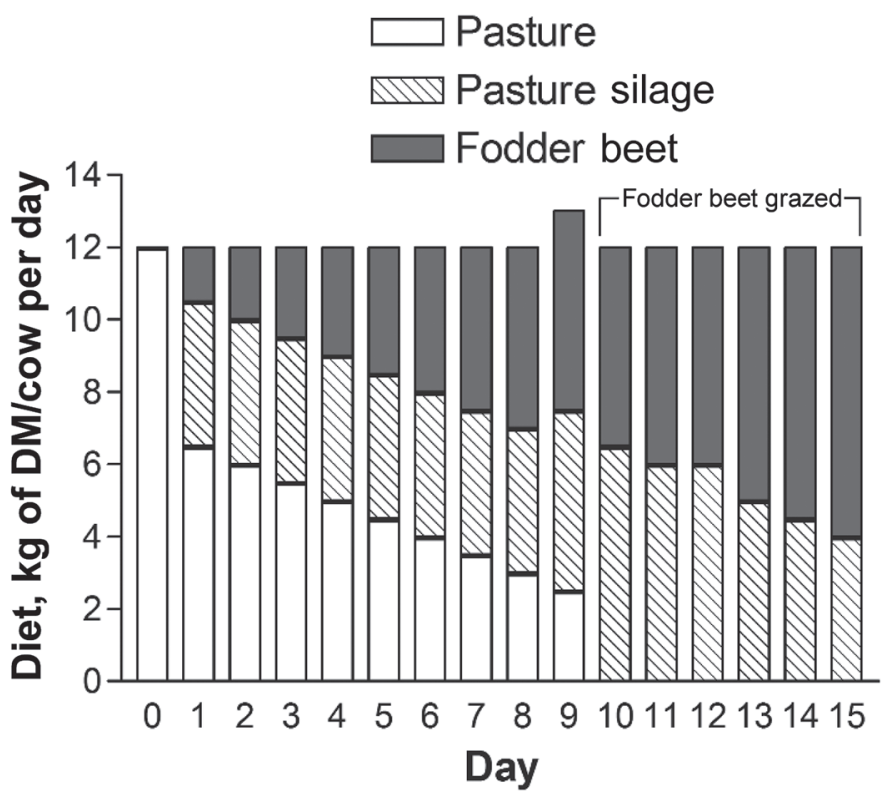

Figure 1. Diet allocation for the adaptation period in the cows fed fodder beet (FB). The FB plants were initially lifted and fed to the cows in a pasture paddock. From d 10 onward, the cows grazed the FB crop in situ. The cows were offered $13 \mathrm{~kg}$ of DM/cow per day on d 9 as a cow was removed for suspected acidosis, but the pasture silage allowance was not altered accordingly. By d 15, the cows were offered the full allocation of FB, which continued for a further $10 \mathrm{~d}$.

docks. Composition of the complete diet for PA and BT treatments is presented in Table 2 .

\section{Cow Measurements}

Body weight and BCS (10-point scale, where 1 is emaciated and 10 is obese; Roche et al., 2004) were determined before treatment start and then at d 9 (adaptation period) and d 22. Blood was sampled from each cow $6 \mathrm{~d}$ after the start of treatment (d 6) and 6 $\mathrm{d}$ after being on the full diet allocation (d 21). Blood was collected from each cow by coccygeal venipuncture into a $10-\mathrm{mL}$ evacuated blood tube (containing lithium heparin; Becton Dickinson, Franklin Lakes, NJ) immediately before the morning feed allocation $(\sim 0700 \mathrm{~h})$. Samples were placed on ice until centrifugation at 1,120 $\times g$ for 12 min at $4^{\circ} \mathrm{C}$. Plasma was harvested and stored at $-20^{\circ} \mathrm{C}$ while awaiting subsequent analyses.

Analyses of metabolites were performed on a Modular P800 analyzer (Roche, Basel, Switzerland) at $37^{\circ} \mathrm{C}$ by Gribbles Veterinary Pathology Ltd. (Hamilton, New Zealand). Nonesterified FA (NEFA) were measured $(\mathrm{mmol} / \mathrm{L})$ using the acyl Co-A synthetase-acyl-CoA oxidase colorimetric method with an NEFA C Kit from Wako (Osaka, Japan). Roche reagent kits were used to measure serum concentrations of albumin $(\mathrm{g} / \mathrm{L}$; bro- 
Table 1. Mean (SD in parentheses) nutrient composition ${ }^{1}$ and $\mathrm{ME}^{2}$ content of feeds

\begin{tabular}{|c|c|c|c|c|c|}
\hline Item, $\%$ of DM unless noted & Pasture & $\begin{array}{l}\text { Corn } \\
\text { silage }\end{array}$ & $\begin{array}{c}\text { Fodder } \\
\text { beet leaf }\end{array}$ & $\begin{array}{c}\text { Fodder } \\
\text { beet bulb }\end{array}$ & $\begin{array}{c}\text { Pasture } \\
\text { silage }\end{array}$ \\
\hline $\mathrm{DM}, \%$ & $10.8(0.76)$ & $31.7(0.60)$ & $14.5(2.13)$ & $17.1(0.29)$ & $49.2(12.99)$ \\
\hline $\mathrm{ME}, \mathrm{MJ} / \mathrm{kg}$ of $\mathrm{DM}$ & $11.0(0.19)$ & 11.2 & & & $10.6(0.78)$ \\
\hline Ash & $10.7(0.52)$ & 4.0 & 13.9 & 5.7 & $9.2(0.37)$ \\
\hline $\mathrm{CP}$ & $22.5(1.02)$ & 8.7 & 24.1 & 6.0 & $15.1(0.65)$ \\
\hline Lipid & $4.0(0.21)$ & 3.2 & 1.9 & 1.7 & $3.3(0.37)$ \\
\hline Starch & $0.6(0.52)$ & 32.8 & $<0.5$ & 2.3 & $1.0(0.18)$ \\
\hline Digestible $\mathrm{OM}$ in DM, \% & $68.9(1.28)$ & 70.0 & 80.6 & 94.8 & $66.3(4.84)$ \\
\hline Soluble sugars & $7.3(1.03)$ & $<0.5$ & 9.1 & 63.6 & $8.7(1.49)$ \\
\hline
\end{tabular}

${ }^{1}$ Nutrient composition was measured by near-infrared reflective spectroscopy and analyzed by Hill Laboratories (Hamilton, NZ).

${ }^{2}$ The ME of pasture and silages was calculated from digestibility of OM in DM $\times 0.16$ (Equation 1.12E in CSIRO, 2007). The ME was not calculated for fodder beet due to this method providing inaccurate predictions (for discussion, see Edwards et al., 2014).

mocresol green reaction at $\mathrm{pH} 4.1$ ), aspartate aminotransferase (AST; IU/L; conversion of $\alpha$-oxoglutarate and L-aspartate to L-glutamate and oxaloacetate), glutamate dehydrogenase (GLDH; IU/L; reduction of $\alpha$-oxoglutarate), GGT (IU/L; production of 5-amino2-nitrobenzoate), total protein (g/L; biuret method), $\mathrm{BHB}$ (mmol/L; reduction of NAD to NADH during oxidation of D-3-hydroxybutyrate to acetoacetate), and bilirubin ( $\mu \mathrm{mol} / \mathrm{L}$; quantitative diazo method). Haptoglobin was measured using the colorimetric haptoglobin assay (TP-801; Tridelta Development Ltd., Kildare, Ireland). The inter- and intra-assay coefficients of variation were $<5 \%$ for all assays.

\section{Liver Tissue Sampling}

Liver tissue was biopsied from a randomly selected subset of animals $(\mathrm{n}=12)$ in each treatment group on d 7 and 21. One of the BT cows and 3 PA cows were removed from the case study; therefore, only samples from the 10 remaining $\mathrm{BT}$ cows and 9 remaining PA cows were used. Tissue was sampled per Lucy et al. (2009). In brief, a region on the right rib cage at the 11 th intercostal space was clipped and cleansed. Local anesthetic (2\% lignocaine; Lopaine, Ethical Agents, Auckland, NZ) was administered and the skin was penetrated with a scalpel. Samples of approximately $200 \mathrm{mg}$ were collected using a liver biopsy needle (12 gauge $x$ $20 \mathrm{~cm}$ ) and immediately placed in screw-capped microcentrifuge tubes and frozen in liquid nitrogen. Samples were stored at $-80^{\circ} \mathrm{C}$ until RNA was extracted.

\section{Extraction of RNA and cDNA Synthesis}

Total cellular RNA was isolated from liver samples ( $\sim 30 \mathrm{mg}$ ) using a TissueLyser II and RNeasy kit (Qia- gen, Hilden, Germany) according to the manufacturer's instructions and then treated with recombinant DNase (DNA-free kit; Ambion, Austin, TX). Quantity and purity of the RNA were determined by spectrophotometry using an ND-1000 (Nano-Drop Technologies, Wilmington, DE). The absorbance ratio at 260:280 $\mathrm{nm}$ of all samples was $>1.8$. The RNA integrity was determined using the Agilent 2100 Bioanalyzer with an RNA 6000 Nano LabChip kit (Agilent Technologies, Palo Alto, $\mathrm{CA}$ ), and an RNA integrity score minimum cut-off of

Table 2. Composition ${ }^{1}$ and $\mathrm{ME}^{2}$ content of the complete diet of cows offered pasture ( $8 \mathrm{~kg}$ of $\mathrm{DM} /$ cow per day) and corn silage (4 $\mathrm{kg}$ of $\mathrm{DM} /$ cow per day; PA; $\mathrm{n}=15)$ or fodder beet $(8 \mathrm{~kg}$ of $\mathrm{DM} / \mathrm{cow}$ per day) and pasture silage ( $4 \mathrm{~kg}$ of $\mathrm{DM} / \mathrm{cow}$ per day; $\mathrm{BT} ; \mathrm{n}=15)$ for 10 $\mathrm{d}$ during the nonlactating period ${ }^{3}$

\begin{tabular}{lrr}
\hline Item, \% of DM unless noted & PA & BT \\
\hline ME, MJ/kg of DM & 11.1 & \\
ADF & 25.7 & 15.2 \\
Ash & 8.4 & 7.5 \\
CP & 17.7 & 10.4 \\
Lipid & 3.7 & 2.2 \\
NDF & 44.5 & 22.6 \\
NSC & 25.6 & 57.3 \\
Starch & 11.7 & 1.7 \\
Digestible OM in DM, \% & 69.3 & 83.4 \\
Soluble sugars & 4.9 & 41.2 \\
\hline
\end{tabular}

${ }^{1}$ Nutrient composition was measured by near-infrared reflective spectroscopy and analyzed by Hill Laboratories (Hamilton, NZ). Diet compositions are based on the full diet allocations, the actual pasture eaten estimated to be $7.6 \mathrm{~kg}$ of $\mathrm{DM} /$ cow during this time, and a $\mathrm{DM}$ percentage of $89 \%$ bulb and $11 \%$ leaf for fodder beet.

${ }^{2}$ The ME of pasture and silages was calculated from digestibility of $\mathrm{OM}$ in $\mathrm{DM} \times 0.16$ (Equation 1.12E in CSIRO, 2007). The ME was not calculated for fodder beet due to this method providing inaccurate predictions (for discussion, see Edwards et al. (2014).

${ }^{3}$ Cows were transitioned onto the fodder beet over a 2 -wk period ( $d$ 0-14) and then fed the full allowance for $10 \mathrm{~d}$ (d 15-24). 
$6.7(7.5 \pm 0.4 ;$ mean $\pm \mathrm{SD})$ was used. All RNA samples met this cut-off and were stored at $-80^{\circ} \mathrm{C}$.

Using the SuperScript III First-Strand Synthesis SuperMix kit (Life Technologies, Auckland, New Zealand), cDNA was synthesized from $2 \mu \mathrm{g}$ of each RNA sample (final volume $=40 \mu \mathrm{L}$ ). Total RNA was reverse transcribed using a final concentration of $27 \mu M$ random pentadecamer primers according to the manufacturer's instructions. Reverse-transcriptase negative controls were generated by excluding the enzyme. The cDNA samples were stored at $-20^{\circ} \mathrm{C}$.

\section{Quantitative PCR}

Using reverse-transcription quantitative PCR (RTqPCR) analysis, hepatic expression of 24 target genes was measured (Supplemental Table S1, https://doi .org/10.3168/jds.2018-16009). Genes were targeted for their involvement in the methionine cycle, gluconeogenesis, lipid synthesis and transport, oxidative stress, and inflammation.

Assays were designed to publicly available bovine gene sequences from the National Center for Biotechnology Information (http://www.ncbi.nlm.nih.gov/ gene). Assays were designed using Roche Universal Probe Library design software to span an intron-exon boundary to prevent amplification of genomic DNA. The specificity of assays was tested using BLAST (http://blast.ncbi.nlm.nih.gov/Blast.cgi; Altschul et al., 1990). The primer and probe sequences and location of the assays are presented in Supplemental Table S1. Primers were manufactured by Integrated DNA Technologies (Coralville, IA) at $25 \mathrm{n} M$ concentration and purified by desalting.

The RTq-PCR was performed using Roche master mix (LightCycler 480 Probes Master) and Roche Universal Probe Library assays analyzed on the Roche LightCycler 480 (Roche Diagnostics, Mannheim, Germany). Each RTq-PCR reaction volume was $10 \mu \mathrm{L}$, consisting of $4 \mu \mathrm{L}$ of $\mathrm{cDNA}$ and $6 \mu \mathrm{L}$ of master mix ( $5 \mu \mathrm{L}$ of Roche Probes Master, $0.4 \mu \mathrm{L}$ each of $5 \mu M$ primer, 0.05 or $0.1 \mu \mathrm{L}$ of probe, and 0.15 or $0.1 \mu \mathrm{L}$ of $\mathrm{H}_{2} \mathrm{O}$ ). Reactions were set up using an epMotion 5075 robot (Eppendorf, Macquarie Park, NSW, Australia) before plates were transferred into the LightCycler 480. Standard cycling conditions were used: $95^{\circ} \mathrm{C}$ for $10 \mathrm{~min}$, $\left(95^{\circ} \mathrm{C}\right.$ for $10 \mathrm{~s}, 60^{\circ} \mathrm{C}$ for $\left.30 \mathrm{~s}\right) \times 45$ cycles, and $40^{\circ} \mathrm{C}$ for $40 \mathrm{~s}$. Each RT-qPCR run included negative controls (no cDNA or no reverse transcriptase). Triplicate measurements were performed for all samples. Assays were tested for specificity by running an agarose gel of the PCR products to ensure amplicon specificity and length.
A relative standard curve was generated for each assay using a 6-point serial cDNA dilution, ranging from $3.33 \mathrm{e}-1$ to $1.37 \mathrm{e}-3$ or $2.00 \mathrm{e}-1$ to $3.2 \mathrm{e}-4$, and the Roche LightCycler 480 software second-derivative maximum analysis. Standard curves for which the coefficient of variation for each triplicate measurement was $<2 \%$ were subsequently used to quantify the experimental samples. The PCR efficiencies of each assay are described in Supplemental Table S1 (https://doi.org/ 10.3168/jds.2018-16009). Endogenous control genes were tested across all samples and their suitability was determined using NormFinder and GeNorm (Vandesompele et al., 2002; Andersen et al., 2004); COX4I1 and $A C T B$ were the 2 most stably expressed genes, the combined stability values of which were 0.205 (GeNorm) and 0.047 (Normfinder). The Roche LightCycler 480 software was used to perform advanced relative quantification analysis of each target gene's expression using the normalization factor of each of the 2 endogenous control genes. The geometric mean of the resulting target:endogenous control ratio for each sample was then calculated. Expression ratios were subsequently normalized to the sample with the lowest ratio to simplify statistical analysis and interpretation.

\section{Statistical Analyses}

Body weight and BCS measures from 1 wk before treatment start were used as covariates in their respective statistical analyses. Repeated measurements through time were modeled for BW, BCS, and plasma metabolite data using REML, including covariate, biopsy (yes vs. no), and diet as fixed effects and cow as a random effect in GenStat (version 16; VSN International, Hemel Hempstead, UK). As treatment $\times$ time interactions $(P<0.001)$ were present, data were also analyzed by week. Data for AST, bilirubin, GGT, GLDH, haptoglobin, BHB, NEFA, and each gene were $\log _{10}$ transformed before analysis due to heterogeneity of variance. Data were then analyzed using ANOVA in GenStat, including cow as a blocking factor with diet, time, and the interaction of diet with time as fixed effects. Treatment means and the standard error of the difference between means are presented. Differences in data were considered significant when $P<0.05$ and discussed as a trend, where appropriate, when $P \leq 0.10$.

\section{RESULTS}

The average FB plant was $11 \%$ DM leaf and $89 \%$ DM bulb (Table 1). The BT cows were $18 \mathrm{~kg}$ heavier than PA cows by the end of the treatment period. The weight gain was not reflected in BCS, as this remained stable throughout the experiment (Figure 2). 

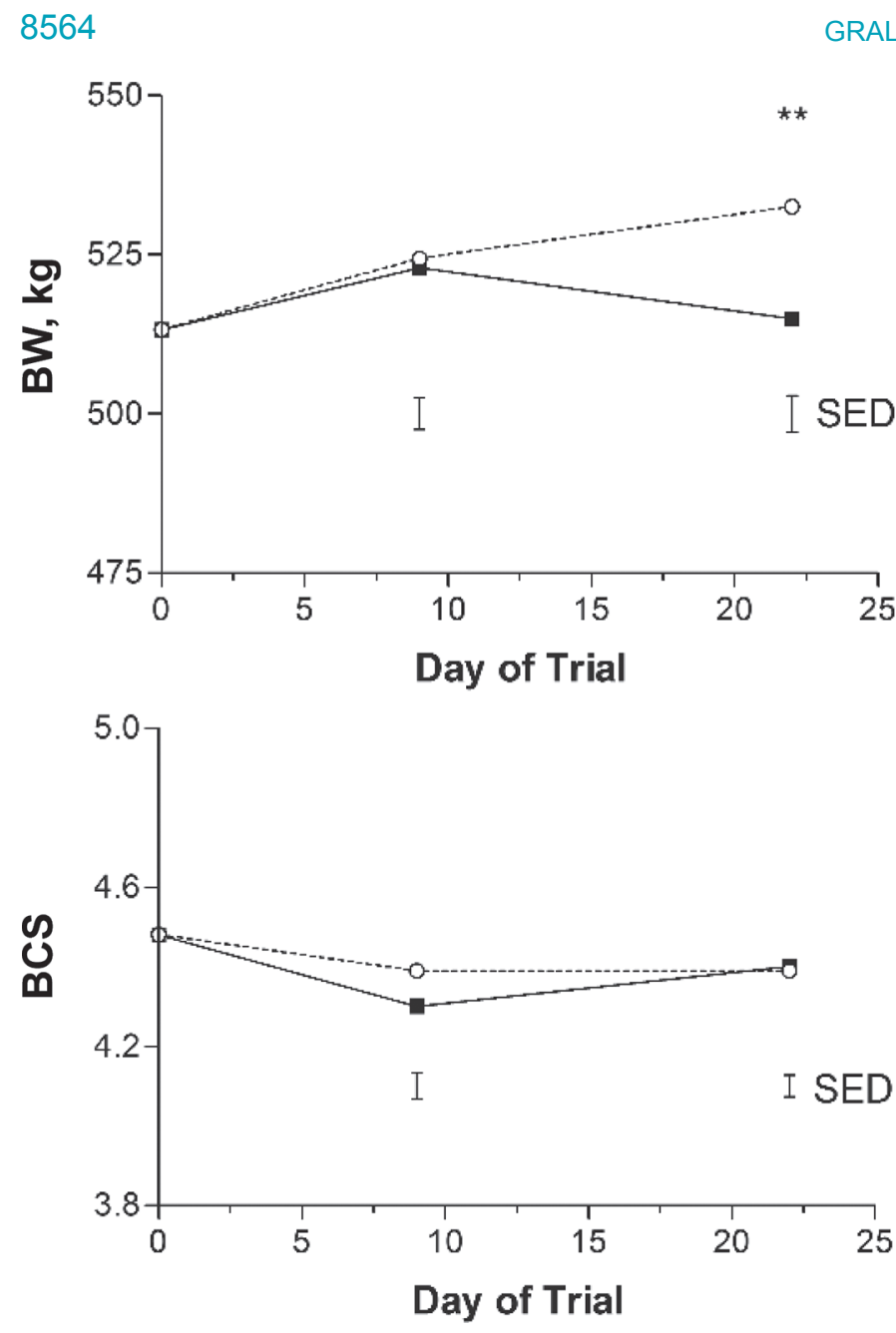

Figure 2. Twice-weekly BW and BCS (10-point scale, where 1 is emaciated and 10 is obese; Roche et al., 2004) from dairy cows fed pasture ( $8 \mathrm{~kg}$ of $\mathrm{DM} /$ cow per day) and corn silage $(4 \mathrm{~kg}$ of $\mathrm{DM} /$ cow per day; $\mathrm{n}=12 ; \boldsymbol{\square})$ or fodder beet $(8 \mathrm{~kg}$ of $\mathrm{DM} /$ cow per day) and pasture silage $(4 \mathrm{~kg}$ of $\mathrm{DM} /$ cow per day; $\mathrm{n}=13$; $\bigcirc$ ) for $24 \mathrm{~d}$ during the nonlactating period. Cows were transitioned onto the fodder beet over a 2-wk period (d $0-14)$ and then fed the full allowance for $10 \mathrm{~d}$ (d 15-24). Means and the SE of the difference (SED) are presented. ** $P<0.01$.

Concentrations of AST, bilirubin, and GLDH were lower in the plasma of BT cows compared with PA cows throughout the experiment (Table 3). Total protein, albumin, and globulin concentrations were also lower in BT cows during the treatment period, whereas plasma concentrations of haptoglobin were greater during the treatment period. Concentrations of BHB were lower during the adaptation period and NEFA were lower during the treatment period in BT cows compared with PA cows.

Expression of genes involved in the methionine cycle were altered by the BT diet. Expression of BHMT was greater in $\mathrm{BT}$ cows relative to PA cows during the adaptation period, and expression of MAT1A was greater

in BT cows, on average, over both periods (Table 4). Expression of HSPA5 was also altered by diet, but the effect was time dependent: HSPA5 expression was greater in $\mathrm{BT}$ cows during the adaptation period but lower during the treatment period. The expression of ATF 4 followed a similar pattern; however, the day $\times$ time interaction was significant, whereas the effects at each time point were not $(P=0.15)$. Diet did not affect the expression of XBP1, GCLC, GPX3, HP, NFKB1, SOD1, or STAT3.

Expression of ACOX1 and ACSL1 was greater in BT cows during the adaptation period (Table 5), and expression of CPT1A and HMGCS2 was greater during the treatment period compared with PA cows. Expression of IDH2 was greater during the treatment period in BT cows, and PCK1 expression was greater during both the adaptation and treatment periods in BT cows compared with PA cows. Expression of FBP1 was not altered during the experiment (Table 5). The BT cows also had greater expression of $A R G 1$ during the treatment period compared with PA cows.

\section{DISCUSSION}

An experiment designed to evaluate the effect of nonlactating cow diet on urinary nitrogen output offered us a unique opportunity to undertake a quantitative case study to evaluate the effects of a high proportion of dietary FB on liver metabolism and systemic inflammatory state. Adapting to the FB diet resulted in transcriptional changes in the unfolded protein response, the methionine cycle, and hepatic glucose and lipid metabolism. Many of these effects, however, were minimal by the time the cows had adjusted to their full FB allocation. During the treatment period, changes in circulating biomarkers of liver health indicated potential positive effects of $\mathrm{FB}$; however, this may reflect differences in nutrient supply limitations rather than an indication of liver health.

The average FB plant used in this study had a slightly lower leaf:bulb ratio than previously reported (Chakwizira et al., 2014), probably a result of climatic conditions. Temperatures in April and May were above average $\left(>1.2^{\circ} \mathrm{C}\right)$ and rainfall was $50 \%$ of normal in April in the region where the farm was located (https: //www.niwa.co.nz/climate/monthly). All other characteristics of $\mathrm{FB}$ were within previously published ranges (Dalley et al., 2017).

Concentrations of the plasma proteins and metabolites associated with hepatic health initially appeared to indicate that the liver of BT cows was in a metabolically superior state compared with PA cows, with lower concentrations of AST, GLDH, and GGT. However, the 
relationships between these metabolites indicate that it is not straightforward. During hepatic disorders, albumin tends to decrease and the concentrations of acute phase proteins (e.g., haptoglobin) increase, thereby changing the albumin:globulin ratio; a decline in this ratio, therefore, is regarded as an indicator of metabolic stress. In the BT cows, both albumin and globulin are lower, reducing the total protein concentration. Few studies report similar results; however, O'Mara et al. (2000) reported that cows provided with supplementary undegradable dietary protein had increased plasma albumin and total protein. The BT diet was lower in CP percentage than the PA diet. Therefore, it is possible that the BT diet may be reducing the synthesis of these proteins due to limitations in AA availability (Pacheco et al., 2016).
The lower concentrations of AST, bilirubin, and GLDH were surprising because we hypothesized that a diet high in FB would lead to rumen acidosis- or SARA-induced systemic inflammation and associated hepatic stress; furthermore, these changes are not consistent with the changes in blood haptoglobin concentrations. However, Rodríguez-Lecompte et al. (2014) also reported no change in GGT or AST in cows with induced SARA via grain or alfalfa pellets. This result is consistent with Humer et al. (2015), who reported no effects of acidosis on AST, GGT, GLDH, or bilirubin in grain-fed cows. In contrast, however, Jiang et al. (2014) reported an increase in GLDH protein expression by the liver in response to SARA, induced by a high-concentrate diet. Therefore, the effects of ruminal acidosis on the concentration of liver enzymes in blood

Table 3. Average concentrations of plasma metabolites from dairy cows fed pasture ( $8 \mathrm{~kg}$ of DM/cow per day) and corn silage (4 kg of DM/ cow per day; PA; $\mathrm{n}=9$ ) or fodder beet $(8 \mathrm{~kg}$ of $\mathrm{DM} /$ cow per day) and pasture silage $(4 \mathrm{~kg}$ of $\mathrm{DM} /$ cow per day; $\mathrm{BT}$; $\mathrm{n}=11)$ for $24 \mathrm{~d}$ during the nonlactating period ${ }^{1}$

\begin{tabular}{|c|c|c|c|c|c|c|}
\hline Metabolite & Period & \multicolumn{2}{|c|}{ Diet } & SED & \multicolumn{2}{|c|}{$P$-value } \\
\hline \multirow[t]{2}{*}{ Total protein, $\mathrm{g} / \mathrm{L}$} & Both & 84.1 & 79.5 & 1.88 & $<0.05$ & $<0.001$ \\
\hline & Trt & 87.1 & 77.7 & 2.29 & $<0.001$ & \\
\hline \multirow{2}{*}{ Albumin, $\mathrm{g} / \mathrm{L}$} & Both & 35.6 & 34.1 & 0.81 & 0.06 & 0.21 \\
\hline & Adapt & 35.9 & 35.3 & 1.02 & 0.52 & \\
\hline \multirow{2}{*}{ Globulin, g/L } & Adapt & 45.2 & 46.1 & 1.88 & 0.64 & \\
\hline & Trt & 51.7 & 45.2 & 1.96 & $<0.01$ & \\
\hline \multirow{3}{*}{ Albumin:globulin } & Both & 0.77 & 0.77 & 0.040 & 0.91 & 0.08 \\
\hline & Adapt & 0.82 & 0.78 & 0.045 & 0.37 & \\
\hline & Trt & 0.71 & 0.76 & 0.048 & 0.30 & \\
\hline \multirow{2}{*}{$\mathrm{AST}, \mathrm{IU} / \mathrm{L}$} & Both & 73.0 & 62.6 & 3.90 & $<0.05$ & 0.99 \\
\hline & Adapt & 76.2 & 64.9 & 5.23 & 0.06 & \\
\hline \multirow{2}{*}{ GGT, IU/L } & Adapt & 47.2 & 40.3 & 15.22 & 0.78 & \\
\hline & Trt & 30.5 & 27.6 & 15.75 & 0.97 & \\
\hline \multirow[t]{3}{*}{ GLDH, IU/L } & Both & 21.8 & 10.1 & 4.97 & $<0.01$ & 0.17 \\
\hline & Adapt & 23.9 & 13.3 & 5.81 & $<0.05$ & \\
\hline & Trt & 19.7 & 6.8 & 6.16 & $<0.01$ & \\
\hline \multirow{3}{*}{ Haptoglobin, mg/L } & Both & 64.2 & 74.4 & 5.30 & 0.06 & 0.07 \\
\hline & Adapt & 53.8 & 55.6 & 6.69 & 0.69 & \\
\hline & Trt & 74.6 & 93.2 & 7.15 & $<0.05$ & \\
\hline \multirow{3}{*}{$\mathrm{BHB}, \mathrm{mmol} / \mathrm{L}$} & Both & 0.48 & 0.38 & 0.062 & 0.10 & 0.08 \\
\hline & Adapt & 0.52 & 0.35 & 0.073 & $<0.05$ & \\
\hline & Trt & 0.44 & 0.41 & 0.078 & 0.66 & \\
\hline \multirow[t]{3}{*}{ NEFA, mmol/L } & Both & 0.24 & 0.22 & 0.032 & 0.53 & $<0.01$ \\
\hline & Adapt & 0.23 & 0.28 & 0.038 & 0.20 & \\
\hline & Trt & 0.24 & 0.16 & 0.040 & $<0.05$ & \\
\hline
\end{tabular}

${ }^{1}$ Cows were transitioned onto the fodder beet over a 2-wk period (d 0-14; Adapt) and then fed the full allowance for 10 d (d 15-24; Trt). Plasma aspartate aminotransferase (AST), bilirubin, $\gamma$-glutamyl transferase (GGT), glutamate dehydrogenase (GLDH), haptoglobin, BHB, and nonesterified fatty acid (NEFA) concentrations were $\log _{10}$ transformed before analysis, with back-transformed values presented here. Means and the SE of the difference (SED) are presented for overall effects (both time periods; Both), the adaptation period (Adapt), and the treatment period (Trt). 
are inconsistent, and the pattern of lower AST, bilirubin, and GLDH could be specific to the FB diet.

One potential benefit of an FB diet is the presence of betaine. Fodder beet is high in betaine (Hanson and Wyse, 1982), which can be used as a methyl donor (Eklund et al., 2005; Zhang et al., 2014) if not converted to acetate in the rumen. Betaine degradation experiments in the rumen report a large range in betaine degradation rates: $20 \%$ over 24 h (Nakai et al.,
2013), 40 to $60 \%$ over $24 \mathrm{~h}$ depending on diet (forage vs grain, respectively; Löest et al., 2001), and up to $45 \%$ per hour (Mitchell et al., 1979). Although FB betaine concentrations and the proportion of betaine escaping ruminal degradation were not measured in this study, increased expression of BHMT and MAT1A in BT cows is consistent with a greater hepatic metabolism of betaine resulting in production of S-adenosylmethionine. S-Adenosylmethionine is a methyl donor that has been

Table 4. Stress response hepatic gene expression from dairy cows fed pasture ( $8 \mathrm{~kg}$ of DM/cow per day) and corn silage (4 kg of DM/cow per day; PA; $\mathrm{n}=9)$ or fodder beet $(8 \mathrm{~kg}$ of $\mathrm{DM} / \mathrm{cow}$ per day) and pasture silage $(4 \mathrm{~kg}$ of $\mathrm{DM} /$ cow per day; BT; $\mathrm{n}=11)$ for $24 \mathrm{~d}$ during the nonlactating period ${ }^{1}$

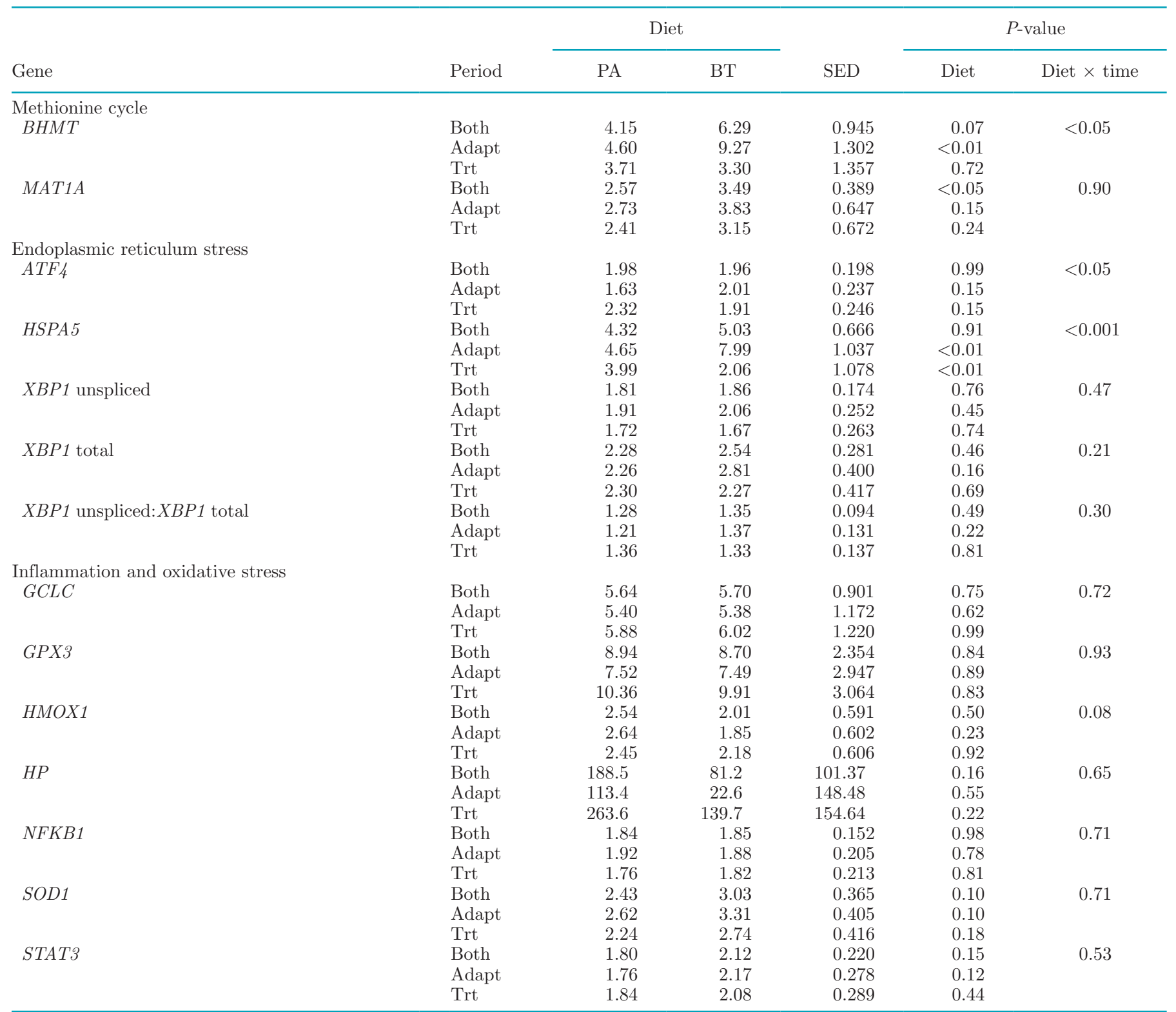

${ }^{1}$ Cows were transitioned onto the fodder beet over a 2-wk period (d 0-14; Adapt) and then fed the full allowance for 10 d (d 15-24; Trt). Means and the SE of the difference (SED) are presented. Data were normalized to COX 41 and ACTB gene expression and are expressed as $\log _{10}$-transformed arbitrary units for overall effects (both time periods; Both), the adaptation period (Adapt), and the treatment period (Trt). 
reported to lower the inflammatory response to LPS (Pfalzer et al., 2014); therefore, if our hypothesis is correct that betaine in FB is escaping ruminal degradation, this may be mitigating some of the negative effects of the high sugar content of the diet. Future work determining the betaine content of $\mathrm{FB}$ and the presence of betaine in the blood would be useful in determining the mechanism behind the lower concentrations of plasma markers of liver damage in BT cows. Alternatively, the upregulation of BMHT and MAT1A mRNA may occur in response to changes in FA absorption, as it has been previously reported that genes in the methionine cycle are modified by PUFA in HepG2 cells and rat liver (Huang et al., 2012, 2013).

There are indications that the FB diet induced a minor unfolded protein response in the liver of the BT cows as they adapted to the dietary change. Expression of ATF 4 and HSPA5 was greater while the BT cows were adapting to their diet, possibly indicating that the endoplasmic reticulum (ER) is under stress (Ron and Walter, 2007; Gessner et al., 2014). An accumulation of unfolded or misfolded proteins in the ER lumen activates the unfolded protein response, which aims to restore ER homeostasis. The response involves activation

Table 5. Metabolic hepatic gene expression from dairy cows fed pasture ( $8 \mathrm{~kg}$ of DM/cow per day) and corn silage (4 kg of DM/cow per day; $\mathrm{PA} ; \mathrm{n}=9)$ or fodder beet $(8 \mathrm{~kg}$ of $\mathrm{DM} /$ cow per day) and pasture silage $(4 \mathrm{~kg}$ of DM/cow per day; BT; $\mathrm{n}=11)$ for $24 \mathrm{~d}$ during the nonlactating period $^{1}$

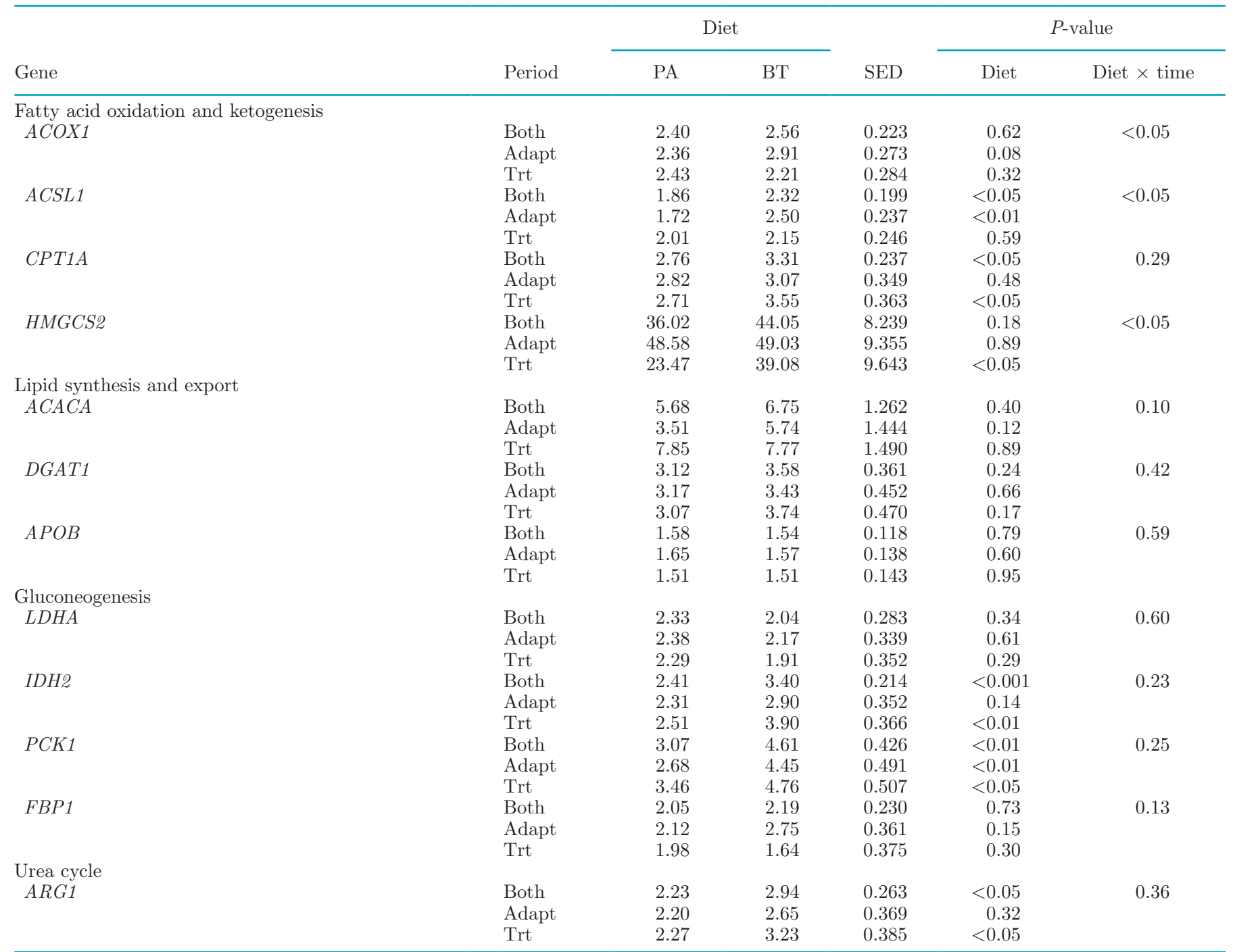

${ }^{1}$ Cows were transitioned onto the fodder beet over a 2-wk period (d 0-14; Adapt) and then fed the full allowance for 10 d (d 15-24; Trt). Means and the SE of the difference (SED) are presented. Data were normalized to COX 411 and ACTB gene expression and are expressed as $\log _{10}$-transformed arbitrary units for overall effects (both time periods; Both), the adaptation period (Adapt), and the treatment period (Trt). 
of HSPA 5 transcription, as the protein product assists in the refolding of proteins. The response also includes restriction of protein translation through the actions of ATF4 (Ron and Walter, 2007), which is supported by the lower concentrations of the hepatic proteins (albumin, globulin) in the bloodstream of the BT cows. The unfolded protein response has also been reported to induce an acute phase response by increasing $\mathrm{TNF} \alpha$ and haptoglobin (Zhang et al., 2006). Indeed, plasma concentrations of haptoglobin were increased during the treatment period in these BT cows. As the effects on transcription of genes involved in the unfolded protein response were not present in BT cows during the treatment period, we believe that these effects are short term; however, the greater concentration of haptoglobin during the treatment period does warrant further investigation. The current recommendations for transitioning onto an FB diet appear adequate to ensure that the liver is not unduly stressed by the dietary change, provided the cows are monitored for symptoms of acidosis.

Transitioning nonlactating dairy cows from pasture onto an FB diet increased the transcription of hepatic genes involved in FA oxidation. Expression of both ACOX1 and ACSL1 was increased in BT cows during the adaptation period, indicating increased peroxisomal FA oxidation. This is supported by lower BHB concentrations in BT cows adapting to their diet, as FA would be preferentially shuttled to the peroxisomes rather than the mitochondria. Peroxisomal oxidation preferentially uses long- (C20 to $\mathrm{C} 16)$ or very long(>C20) chain FA (Le Borgne, 2012; Schrader et al., 2015), which are shortened for further processing in the mitochondria. As this result was temporary, it may be due to changes to FA biohydrogenation in the rumen or changes in the composition of absorbed FA into the plasma while the ruminal bacteria and the rumen are adjusting to the dietary change. Pacheco and colleagues (unpublished data; D. Pacheco, AgResearch Grasslands, Palmerston North, New Zealand; S. Muetzel, AgResearch Grasslands; S. Lewis, AgResearch Grasslands; D. Dalley, DairyNZ, Hamilton, New Zealand; M. Bryant, DairyNZ; G. C. Waghorn, DairyNZ ) reported increased molar proportions of propionate, butyrate, valerate, and caproate and decreased proportions of acetate when FB was offered to lactating and nonlactating cows, indicating significant changes in rumen fermentation. Subclinical acidosis has previously been reported to change FA concentrations and increase ACOX1 expression in the liver (Xu et al., 2015); therefore, these changes may also be a result of changes in ruminal $\mathrm{pH}$. In the study by Pacheco and colleagues (unpublished data), average rumen $\mathrm{pH}$ did not differ between treatments during the measurement period, but rumen $\mathrm{pH}$ was below 6 for several hours per day when FB was consumed. Overall, it is likely that the liver is responding to the addition of $\mathrm{FB}$ to the diet through altering FA metabolism.

Transcription of genes involved in the FA metabolism pathway continued to be altered during the treatment period, as expression of CPT1A and HMGCS2 was greater in $\mathrm{BT}$ cows compared with $\mathrm{PA}$ cows during the treatment period. This may also be in response to an increase in peroxisomal oxidation during the adaptation period, by processing the resulting short- and mediumchain FA (Le Borgne, 2012). Increased $\beta$-oxidation of FA results in the production of acetyl-coA, which can then be shuttled toward ketogenesis or through the tricarboxylic acid cycle (Nguyen et al., 2008). Indeed, expression of IDH2 and PCK1 was also increased during the treatment period in BT cows, indicating increased nutrient flow through the TCA cycle and the shuttling of nutrients toward gluconeogenesis. Surprisingly, BHB concentrations in plasma were not significantly different, which may indicate that acetoacetate production was increased (through the actions of HMGCS2) but BHB production was not. The lack of a change in BHB concentrations is consistent with Keogh et al. (2009), who compared cows on $\mathrm{FB}$ with those on grass silage for 5 wk prepartum and reported no differences in plasma BHB concentrations. Plasma concentrations of NEFA were reduced during the treatment period in BT cows compared with PA cows, indicative of reduced lipolysis; this is supported by the greater BW in these cows by the end of the treatment period. It appears that the addition of FB to the diet of grazing cows alters the transcription of genes involved in FA oxidation and ketogenesis in response to the changes in VFA proportions being absorbed across the rumen.

\section{CONCLUSIONS}

The case study offered us a unique opportunity to investigate whether consumption of more than $65 \%$ of the diet as FB by nonlactating dairy cows negatively affected liver metabolism and the inflammatory state. Despite the high sugar content of FB, plasma and hepatic markers of inflammation and oxidative stress were not negatively affected beyond the adaptation period, indicating that systemic acidosis was not occurring to any great extent. However, there may be minor carryover effects with regards to haptoglobin. Further research is required to confirm these results in a larger population and determine the underlying causes of lower plasma concentrations of markers of hepatic damage in cows consuming FB. 


\section{ACKNOWLEDGMENTS}

The authors acknowledge the significant support of Deanne Waugh for on-farm logistics; Jason Phillips and the DairyNZ Scott Dairy Farm team for their management and care of animals; the DairyNZ technical team, in particular Stu Morgan, for technical support; and Barbara Dow for statistical analysis. This project was funded by the Ministry for Business, Innovation, and Employment (DNZ1301, Wellington, New Zealand) and New Zealand dairy farmers through DairyNZ Inc. (RD1422, Hamilton, New Zealand).

\section{REFERENCES}

Abaker, J. A., T. L. Xu, D. Jin, G. J. Chang, K. Zhang, and X. Z. Shen. 2017. Lipopolysaccharide derived from the digestive tract provokes oxidative stress in the liver of dairy cows fed a high-grain diet. J. Dairy Sci. 100:666-678. https://doi.org/10.3168/jds.2016 $-10871$.

Altschul, S. F., W. Gish, W. Miller, E. W. Myers, and D. J. Lipman. 1990. Basic local alignment search tool. J. Mol. Biol. 215:403-410.

Andersen, C. L., J. L. Jensen, and T. F. Ørntoft. 2004. Normalization of real-time quantitative reverse transcription-PCR data: A model-based variance estimation approach to identify genes suited for normalization, applied to bladder and colon cancer data sets. Cancer Res. 64:5245-5250.

Atkins, N. E., E. C. L. Bleach, and L. A. Sinclair. 2015. The effects on performance of out-wintering replacement heifers in a highoutput dairy system. Pages 81-83 in Proc. 18th Symp. European Grassland Federation, Wageningen, the Netherlands. Wageningen Academic Publishers, Wageningen, the Netherlands.

Atkins, N. E., K. Walley, E. C. L. Bleach, and L. A. Sinclair. 2014 A survey of current practice among dairy farmers out-wintering replacement heifers in Great Britain. Page 218 in Adv. Anim. Biosci. Proceedings of the British Society of Animal Science. Cambridge University Press, Cambridge, UK.

Chakwizira, E., J. M. D. E. Ruiter, S. Maley, S. J. Dellow, M. J. George, and A. J. Michel. 2014. Water use efficiency of fodder beet crops. Proc. N.Z. Grassland Assoc. 76:125-134.

Chang, G., S. Zhuang, H. M. Seyfert, K. Zhang, T. Xu, D. Jin, J. Guo, and X. Shen. 2015. Hepatic TLR4 signaling is activated by LPS from digestive tract during SARA, and epigenetic mechanisms contribute to enforced TLR4 expression. Oncotarget 6:38578-38590. https://doi.org/10.18632/oncotarget.6161.

CSIRO. 2007. Nutrient Requirements of Domesticated Ruminants. M. Freer, H. Dove, and J. Nolan, ed. CSIRO, Collingwood, Australia. Dalley, D. E., B. J. Malcolm, E. Chakwizira, and J. M. de Ruiter. 2017. Range of quality characteristics of New Zealand forages and implications for reducing the nitrogen leaching risk from grazing dairy cows. N. Z. J. Agric. Res. 60:319-332. https://doi.org/10 $.1080 / 00288233.2017 .1345762$.

Edwards, G. R., J. M. De Ruiter, D. E. Dalley, J. B. Pinxterhuis, and K. C. Cameron. 2014. Dry matter intake and body condition score change of dairy cows grazing fodder beet, kale and kale-oat forage systems in winter. Proc. N.Z. Grassland Assoc. 76:81-88.

Eklund, M., E. Bauer, J. Wamatu, and R. Mosenthin. 2005. Potential nutritional and physiological functions of betaine in livestock. Nutr. Res. Rev. 18:31-48. https://doi.org/10.1079/NRR200493.

Gessner, D. K., G. Schlegel, R. Ringseis, F. J. Schwarz, and K. Eder. 2014. Up-regulation of endoplasmic reticulum stress induced genes of the unfolded protein response in the liver of periparturient dairy cows. BMC Vet. Res. 10:46. https://doi.org/10.1186/1746-6148-10 -46 .

Gibbs, S. J. 2011. Wintering dairy cows on fodder beet. In Proc. South Island Dairy Event, Invercargill, New Zealand. Paper 4.1. Lincoln University, Lincoln, NZ. http://side.org.nz/past-proceedings/.
Hanson, A. D., and R. Wyse. 1982. Biosynthesis, translocation, and accumulation of betaine in sugar beet and its progenitors in relation to salinity. Plant Physiol. 70:1191-1198. https://doi.org/10 $.1104 /$ pp.70.4.1191.

Huang, T., X. Hu, N. Khan, J. Yang, and D. Li. 2013. Effect of polyunsaturated fatty acids on homocysteine metabolism through regulating the gene expressions involved in methionine metabolism. ScientificWorldJournal 2013:931626.

Huang, T., M. L. Wahlqvist, and D. Li. 2012. Effect of n-3 polyunsaturated fatty acid on gene expression of the critical enzymes involved in homocysteine metabolism. Nutr. J. 11:6.

Humer, E., A. Khol-Parisini, L. Gruber, J. Gasteiner, S. M. AbdelRaheem, and Q. Zebeli. 2015. Long-term reticuloruminal pH dynamics and markers of liver health in early-lactating cows of various parities fed diets differing in grain processing. J. Dairy Sci. 98:6433-6448. https://doi.org/10.3168/jds.2015-9522.

Jiang, X. Y., Y. D. Ni, S. K. Zhang, Y. S. Zhang, and X. Z. Shen. 2014. Identification of differentially expressed proteins in liver in response to subacute ruminal acidosis (SARA) induced by highconcentrate diet. Asian-australas. J. Anim. Sci. 27:1181-1188. https://doi.org/10.5713/ajas.2013.13729.

Keogh, B., P. French, T. McGrath, T. Storey, and F. J. Mulligan. 2009. Effect of three forages and two forage allowances offered to pregnant dry dairy cows in winter on periparturient performance and milk yield in early lactation. Grass Forage Sci. 64:292-303. https://doi.org/10.1111/j.1365-2494.2009.00697.x.

Le Borgne, F. 2012. Interaction between peroxisomes and mitochondria in fatty acid metabolism. Open J. Mol. Integr. Physiol. 2:2733. https://doi.org/10.4236/ojmip.2012.21005.

Löest, C. A., E. C. Titgemeyer, J. S. Drouillard, D. A. Blasi, and D. J. Bindel. 2001. Soybean hulls as a primary ingredient in forage-free diets for limit-fed growing cattle. J. Anim. Sci. 79:766-774.

Lucy, M. C., G. A. Verkerk, B. E. Whyte, K. A. Macdonald, L. Burton, R. T. Cursons, J. R. Roche, and C. W. Holmes. 2009. Somatotropic axis components and nutrient partitioning in genetically diverse dairy cows managed under different feed allowances in a pasture system. J. Dairy Sci. 92:526-539. https://doi.org/10.3168/ jds.2008-1421.

Mitchell, A. D., A. Chappell, and K. L. Knox. 1979. Metabolism of betaine in the ruminant. J. Anim. Sci. 49:764-774.

Nakai, T., T. Sato, M. Teramura, H. Sadoya, M. Ohtani, T. Takahashi, K. Kida, and S. Hidaka. 2013. The effect of a continuous supply of betaine on the degradation of betaine in the rumen of dairy cows. Biosci. Biotechnol. Biochem. 77:666-669. https://doi.org/10.1271/ bbb. 120839 .

Nguyen, P., V. Leray, M. Diez, S. Serisier, J. Le Bloc'h, B. Siliart, and H. Dumon. 2008. Liver lipid metabolism. J. Anim. Physiol. Anim. Nutr. (Berl.) 92:272-283. https://doi.org/10.1111/j.1439 $-0396.2007 .00752 . x$.

O'Mara, F. P., J. J. Murphy, and M. Rath. 2000. The effect of concentrate supplements differing in ruminal protein degradability on milk production and blood metabolite concentrations of dairy cows grazing perennial ryegrass pasture. Livest. Prod. Sci. 64:183-191. https://doi.org/10.1016/S0301-6226(99)00150-5.

Pacheco, D., G. Waghorn, and D. Dalley. 2016. Brief communication: Plasma amino acid profiles of lactating dairy cows fed fodder beet and ryegrass diets. Proc. N.Z. Soc. Anim. Prod. 76:62-64.

Pfalzer, A. C., S.-W. Choi, S. A. Tammen, L. K. Park, T. Bottiglieri, L. D. Parnell, and S. Lamon-Fava. 2014. S-Adenosylmethionine mediates inhibition of inflammatory response and changes in DNA methylation in human macrophages. Physiol. Genomics 46:617623. https://doi.org/10.1152/physiolgenomics.00056.2014.

Plaizier, J. C., E. Khafipour, S. Li, G. N. Gozho, and D. O. Krause. 2012. Subacute ruminal acidosis (SARA), endotoxins and health consequences. Anim. Feed Sci. Technol. 172:9-21. https://doi.org/ 10.1016/j.anifeedsci.2011.12.004.

Plaizier, J. C., D. O. Krause, G. N. Gozho, and B. W. McBride. 2008. Subacute ruminal acidosis in dairy cows: The physiological causes, incidence and consequences. Vet. J. 176:21-31. https://doi.org/10 $.1016 / j . t v j 1.2007 .12 .016$. 
Roche, J. R., P. G. Dillon, C. R. Stockdale, L. H. Baumgard, and J. M. VanBaale. 2004. Relationships among international body condition scoring systems. J. Dairy Sci. 87:3076-3079.

Roche, J. R., E. S. Kolver, and J. K. Kay. 2005. Influence of precalving feed allowance on periparturient metabolic and hormonal responses and milk production in grazing dairy cows. J. Dairy Sci. 88:677-689. https://doi.org/10.3168/jds.S0022-0302(05)72732-6.

Rodríguez-Lecompte, J. C., A. D. Kroeker, A. Ceballos-Márquez, S. Li, J. C. Plaizier, and D. E. Gomez. 2014. Evaluation of the systemic innate immune response and metabolic alterations of nonlactating cows with diet-induced subacute ruminal acidosis. J. Dairy Sci. 97:7777-7787. https://doi.org/10.3168/jds.2014-8319.

Ron, D., and P. Walter. 2007. Signal integration in the endoplasmic reticulum unfolded protein response. Nat. Rev. Mol. Cell Biol. 8:519-529. https://doi.org/10.1038/nrm2199.

Schrader, M., J. Costello, L. F. Godinho, and M. Islinger. 2015. Peroxisome-mitochondria interplay and disease. J. Inherit. Metab. Dis. 38:681-702. https://doi.org/10.1007/s10545-015-9819-7.

Shepherd, M., P. Shorten, D. Costall, and K. A. MacDonald. 2017. Evaluation of urine excretion from dairy cows under two farm systems using urine sensors. Agric. Ecosyst. Environ. 236:285-294.
Vandesompele, J., K. De Preter, F. Pattyn, B. Poppe, N. Van Roy A. De Paepe, and F. Speleman. 2002. Accurate normalization of real-time quantitative RT-PCR data by geometric averaging of multiple internal control genes. Genome Biol. 3:RESEARCH0034.

Xu, T., H. Tao, G. Chang, K. Zhang, L. Xu, and X. Shen. 2015. Lipopolysaccharide derived from the rumen down-regulates stearoylCoA desaturase 1 expression and alters fatty acid composition in the liver of dairy cows fed a high-concentrate diet. BMC Vet. Res. 11:52. https://doi.org/10.1186/s12917-015-0360-6.

Zhang, K., X. Shen, J. Wu, K. Sakaki, T. Saunders, D. T. Rutkowski, S. H. Back, and R. J. Kaufman. 2006. Endoplasmic reticulum stress activates cleavage of CREBH to induce a systemic inflammatory response. Cell 124:587-599. https://doi.org/10.1016/j.cell .2005.11.040.

Zhang, L., W. J. An, H. Lian, G. B. Zhou, Z. Y. Han, and S. J. Ying. 2014. Effects of dietary betaine supplementation subjected to heat stress on milk performances and physiology indices in dairy cow. Genet. Mol. Res. 13:7577-7586. https://doi.org/10.4238/2014 .September.12.25. 